\title{
Researches on the use of textile materials for protection against soil erosion
}

DOI: 10.35530/IT.071.02.1627

BOGDAN-IULIAN DOROFTEI

OVIDIU-GEORGE IORDACHE

MIRCEA DEGERATU

IOANA CORINA MOGA

GEORGETA BANDOC

\section{ABSTRACT - REZUMAT}

\section{Researches on the use of textile materials for protection against soil erosion}

Erosion of sandy soil due to wind action is a global ecological problem with major implications both in the field of agriculture and in the socio-economic sphere. Erosion and sand transport have a negative effect both in the "active area" in which it occurs and outside it, not being a strictly defined phenomenon. The present paper deals with the problems due to the erosion of soils by wind, and the way of diminishing this phenomenon by using some protective textile screens placed transversely to the wind direction. The aim of the paper is to provide numerical contributions on wind interaction with permeable soil protection obstacles. For concrete data, a number of numerical simulations of the air flow in the atmospheric boundary layer area was carried out, in the presence of a wind barrier having different degrees of permeability, depending on the textile used, for the determination of the speed upstream and downstream of the obstacle. The program used for the numerical simulation is ANSYS Fluent ${ }^{\mathrm{TM}}$, a computational fluid dynamics software that uses a variety of equations for the modelling of fluid flow. The results obtained will be used as a basis for further research, based on scaled textile barriers models for physical experiments in the aerodynamic tunnel.

Keywords: environmental protection, wind soil erosion, protection textile screens, numerical simulations, turbulent $k-\varepsilon$ model

\section{Cercetări privind folosirea materialelor textile pentru protecţia împotriva eroziunii solului}

Eroziunea solului nisipos, din cauza acţiunii vântului, reprezintă o problemă ecologică globală cu implicaţii majore atât în domeniul agriculturii, cât şi în sfera socio-economică. Eroziunea şi transportul nisipului au un efect negativ atât în „zona activă”, în care are loc, cât şi în afara acesteia, nefiind un fenomen strict definit. Lucrarea de faţă tratează problemele cauzate de eroziunea solurilor de către vânturi şi modul de diminuare al acestui fenomen, prin utilizarea de ecrane textile de protecţie plasate transversal pe direcţia vântului. Scopul lucrării este de a oferi contribuţii numerice asupra interacţiunii vântului cu obstacolele permeabile de protecţie ale solului. Pentru date concrete, a fost efectuat un număr de simulări numerice ale fluxului de aer în zona stratului de delimitare atmosferică, în prezenţa unei bariere de vânt cu diferite grade de permeabilitate, în funcţie de materialul textil folosit, pentru determinarea vitezei în amonte şi în aval de obstacol. Programul folosit pentru simulare numerică este ANSYS Fluent ${ }^{T M}$, un software de dinamică computaţională a fluidelor, care utilizează o varietate de ecuaţii pentru modelarea fluxului de fluide. Rezultatele obţinute vor fi utilizate ca bază pentru cercetări ulterioare, folosind modele scalate de bariere textile, pentru experimente fizice în tunelul aerodinamic.

Cuvinte-cheie: protecţia mediului, eroziune sol cauzată de vânt, ecrane textile de protecţie, simulări numerice, model $k-\varepsilon$ turbulent

\section{INTRODUCTION}

Soil degradation constitutes a grave environmental global issue, taking into account numerous negative implications ecologically and socio-economically. One of the causes of soil degradation is wind erosion. This phenomenon is growing in areas lacking tall vegetation, such as forests, especially in the fields of agriculture where soil degradation has a devastating impact on crops. The vegetal soil is gradually removed by wind erosion, leaving the land untouched and unproductive, the plants being unable to develop their roots, thus generating a decrease in the production of cereal and vegetable plants. Another effect caused by wind erosion is the rise of dust clouds. This phenomenon, once developed in populated areas, has a detrimental impact on the health of the human body due to inhalation of dust particles by humans. These non-organic particles once inhaled can cause lung problems and also other organs, such as the brain or the liver when the smaller particles are dissolved in the blood stream. Dust clouds can also affect air or road transportation, because particles suspended in the vicinity of an airport or motorway can make visibility more difficult and sometimes even make vehicles unable to move due to damage to their engines or their fuselage. Erosion has a negative socio-economic impact on the area affected by this phenomenon, which leads to the need to conduct different studies to establish some methods of controlling its effect. A method to avoid or mitigate negative effects is related to the use of protection barriers that play an essential role in 
establishing and maintaining ecological and socioeconomic equilibrium in the region. They have a key role to play in combating soil erosion, fixing sandy soils, protecting against mechanical damage to crops (by deflation), regulating soil moisture (by retaining snow in winter which is an essential spring moisture intake), stopping/reducing clogging local hydro-technical installations etc. [1-5]. Another method of limiting and even eliminating the effects of wind erosion of land is the one studied in this article and refers to the use of textile barriers placed perpendicular to the direction of the wind in order to reduce its intensity.

\section{NUMERICAL SIMULATION}

\section{Objective}

Wind erosion takes place through the entrainment of fine particles by the wind, these being transported, depending on their size and the intensity of the wind, by rolling, saltation or suspension, the latter being encountered in case of dust clouds. In order to eliminate the phenomenon, it is proposed to raise textile barriers in the wind direction in order to reduce the wind speed downstream of them, thus protecting the area of interest and diminishing the transport of the particles. Thus, for the numerical simulation in the present paper a calculation model will be made with the help of the ANSYS Fluent ${ }^{\mathrm{TM}}$ finite element calculation program which will track how the wind velocity is reduced downstream of the obstacle made of textile material at certain distances predetermined and for varying degrees of permeability. The results of the numerical tests will be presented synthetically in a table then in graphical form to highlight the way in which the wind speed is downgraded downstream of the permeable obstacle.

\section{Textile materials used in the tests}

To achieve the numerical experiment, five polypropylene (PE) textiles were proposed that are usually used in the medical field, each having a certain porosity and specific weight [6-7]. The porosity of the materials varies between $58 \%$ and $78 \%$ and can be found in table 1.

Table 1

PARTICULARITIES OF TEXTILE MATERIALS USED IN NUMERICAL TESTS

\begin{tabular}{|l|c|c|}
\hline \multicolumn{1}{|c|}{ Material } & Weight $\mathbf{( g / \mathbf { c m } ^ { 2 } )}$ & Porosity $\mathbf{( \% )}$ \\
\hline Gynemesh PS & 42 & 64 \\
\hline UltraPro & 28 & 69 \\
\hline SmartMesh & 19 & 78 \\
\hline Novasilk & 21 & 72 \\
\hline Polyform & 40 & 58 \\
\hline
\end{tabular}

\section{Numerical method used}

The phenomenon studied takes place inside the atmospheric boundary layer, the wind speed being directly influenced by the roughness of the land taken into consideration [8-11]. Thus, the calculation hypothesis will be for a flow in the turbulent field corresponding to the $k-\varepsilon$ model, with specific equations of this very common model used in Computational Fluid Dynamics (CFD) calculations. The geometry of the model is very simple, the flow domain being framed in a small side rectangle with a height of $200 \mathrm{~mm}$ and a length of $700 \mathrm{~mm}$. At a distance of $100 \mathrm{~mm}$ from the inlet, the permeable obstacle is found, having a height $H=40 \mathrm{~mm}$. The boundary conditions for the simulation are a constant velocity $v_{0}=21 \mathrm{~cm} / \mathrm{s}$ for the inlet (the left side of the rectangle), and a pressure $P_{\text {atm }}=0$ (zero) for the output from the domain (the rightmost side of the rectangle). The bottom side was modeled as a "wall" structure with the "no-slip" option enabled, which simulates the roughness of the land in the area of interest. The large opposite side of this, the upper boundary is of the "symmetry" type to simulate the atmospheric layer [6]. Also, for the fluid domain, the air density value $\rho=1.225 \mathrm{~kg} / \mathrm{m}^{3}$ and the air viscosity $\mu=1.7894 \mathrm{e}-05 \mathrm{~kg} /(\mathrm{m} \cdot \mathrm{s})$ were introduced. The permeable barrier was assigned, for each simulation performed, a different permeability, depending on the studied material. The study domain can be seen in figure 1.

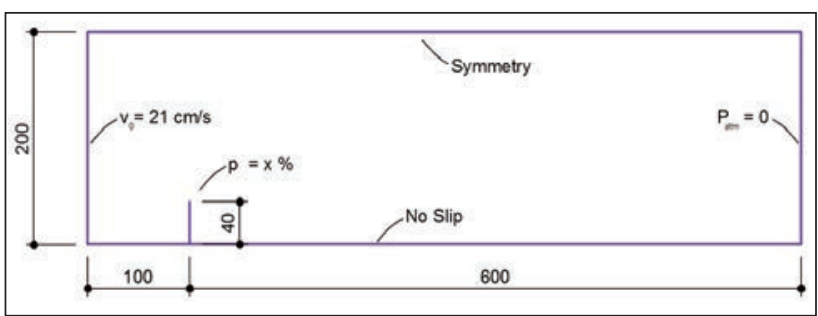

Fig. 1. The geometry of the numerical simulation domain

For the boundary condition of the obstacle we used the "porous jump" option using the equation:

$$
\Delta p=-\left(\frac{\mu}{\alpha} v+C_{2} \frac{1}{2} \rho v^{2}\right) \Delta m
$$

where: $\mu$ is the viscosity of the fluid (air), $\alpha$-obstacle permeability (porosity), $C_{2}$ - pressure loss coefficient, $v$ - the velocity of the air flow perpendicular to the obstacle direction, $\rho$ - density of the fluid (air) and $\Delta m$ - the thickness of the porous obstacle.

The porous thin media has a finite thickness on which the pressure loss is produced, due to a combination of Darcy's law and an additional term of loss of inertia. As a result of the discretization (meshing) of the flow domain for the model, 297404 cells and 298701 nodes were produced (figure 2).

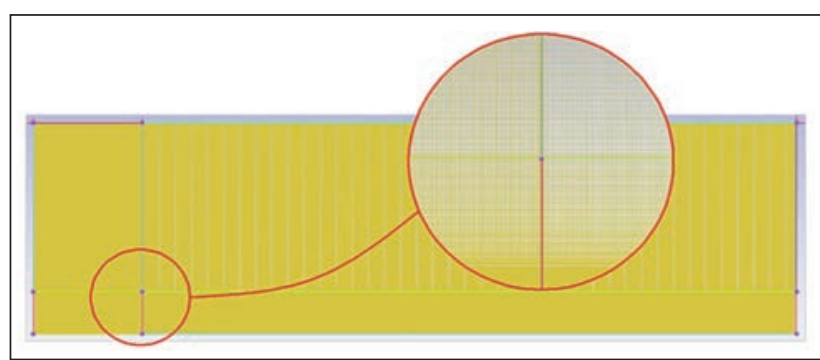

Fig. 2. The flow domain mesh 
After setting the mesh geometric model, and after setting the boundary conditions, we went to the next stage, namely the numerical calculations for each type of textile barrier used and its porosity and its effect upon the air velocity field.

\section{RESULTS AND DISCUSSIONS}

The results of the simulations can be seen in the below images, which contain a graphic for the wind velocity field for the $x$ direction (the air flow direction), for reference, for the barrier porosity $p=0 \%$ (figure 3), a graphic for the wind velocity field for $p=64 \%$ (figure 4), a table with the values of the average speed for certain predetermined heights in the model, and a series of graphs with the comparation of the results obtained for different porosity of the materials and their influence over the wind velocity field.

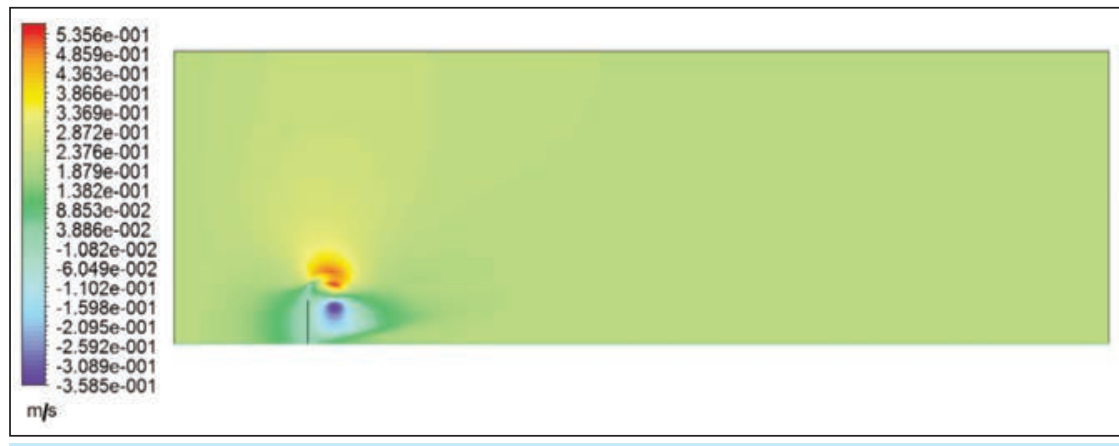

Fig. 3. The contour for the velocity field on $x$ direction, for barrier porosity $p=0 \%$

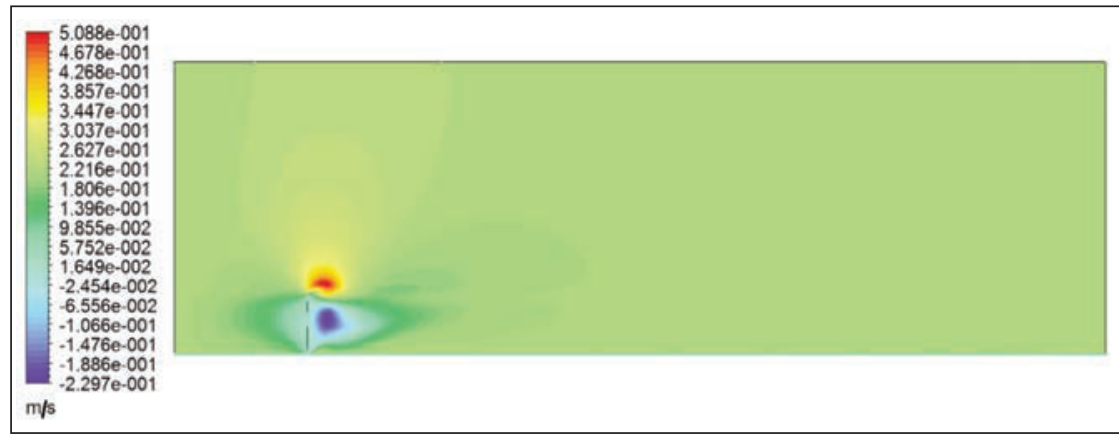

Fig. 4. The contour for the velocity field on $x$ direction, for barrier porosity $p=64 \%$

Table 2

\begin{tabular}{|c|c|c|c|c|c|c|c|c|c|c|c|c|}
\hline \multicolumn{13}{|c|}{$\begin{array}{c}\text { VALUES FOR WIND VELOCITY DOWNSTREAM OF THE BARRIER AT DIFFERENT HEIGHTS, IN REGARD } \\
\text { TO THE POROSITY OF THE MATERIAL (CM/S) }\end{array}$} \\
\hline \multirow{2}{*}{$\begin{array}{c}\text { Height } \\
(\mathrm{mm})\end{array}$} & \multicolumn{6}{|c|}{$x=0.25 H$} & \multicolumn{6}{|c|}{$x=0.50 H$} \\
\hline & $0 \%$ & $64 \%$ & $69 \%$ & $78 \%$ & $72 \%$ & $58 \%$ & $0 \%$ & $64 \%$ & $69 \%$ & $78 \%$ & $72 \%$ & $58 \%$ \\
\hline 0 & 4.59 & 0.92 & 0.92 & 0.91 & 0.92 & 0.92 & 7.76 & 0.89 & 0.89 & 0.89 & 0.89 & 0.89 \\
\hline 25 & 14.70 & 18.36 & 16.86 & 13.70 & 15.81 & 20.19 & 35.79 & 19.02 & 17.56 & 15.21 & 16.70 & 21.29 \\
\hline 50 & 47.92 & 49.86 & 48.57 & 46.12 & 47.71 & 51.32 & 50.03 & 44.21 & 42.53 & 40.01 & 41.56 & 46.83 \\
\hline 75 & 29.44 & 28.58 & 28.42 & 28.10 & 28.31 & 28.82 & 29.10 & 28.11 & 27.93 & 27.60 & 27.81 & 28.39 \\
\hline 100 & 26.02 & 25.62 & 25.53 & 25.37 & 25.48 & 25.74 & 25.85 & 25.50 & 25.42 & 25.25 & 25.36 & 25.63 \\
\hline 150 & 23.67 & 23.54 & 23.49 & 23.40 & 23.46 & 23.62 & 23.69 & 23.58 & 23.53 & 23.43 & 23.49 & 23.65 \\
\hline 200 & 23.09 & 22.99 & 22.96 & 22.88 & 22.93 & 23.06 & 23.09 & 23.00 & 22.97 & 22.89 & 22.94 & 23.06 \\
\hline \multirow{2}{*}{$\begin{array}{l}\text { Height } \\
(\mathrm{mm})\end{array}$} & \multicolumn{6}{|c|}{$x=1 H$} & \multicolumn{6}{|c|}{$x=1.5 H$} \\
\hline & $0 \%$ & $64 \%$ & $69 \%$ & $78 \%$ & $72 \%$ & $\%$ & $0 \%$ & $64 \%$ & $69 \%$ & $78 \%$ & $72 \%$ & $58 \%$ \\
\hline 0 & 12.97 & 0.91 & 0.91 & 0.91 & 0.91 & 0.91 & 15.08 & 0.90 & 0.90 & 0.90 & 0.90 & 0.90 \\
\hline 25 & 2.33 & 3.83 & 4.22 & 4.81 & 4.45 & 3.17 & 11.67 & 11.33 & 11.50 & 11.84 & 11.63 & 11.06 \\
\hline 50 & 27.90 & 23.23 & 23.06 & 22.85 & 22.97 & 23.55 & 20.27 & 18.71 & 18.71 & 17.73 & 18.71 & 18.73 \\
\hline 75 & 25.99 & 25.02 & 24.92 & 24.75 & 24.86 & 25.18 & 22.95 & 22.29 & 22.25 & 22.19 & 22.23 & 22.36 \\
\hline 100 & 24.97 & 24.65 & 24.58 & 24.45 & 24.54 & 24.75 & 23.69 & 23.29 & 23.25 & 23.16 & 23.22 & 23.36 \\
\hline 150 & 23.50 & 23.41 & 23.37 & 23.27 & 23.33 & 23.48 & 23.17 & 23.06 & 23.02 & 22.93 & 22.99 & 23.12 \\
\hline 200 & 23.02 & 22.92 & 22.88 & 22.81 & 22.86 & 22.97 & 22.85 & 22.70 & 22.67 & 22.61 & 22.65 & 22.76 \\
\hline \multirow{2}{*}{$\begin{array}{c}\text { Height } \\
(\mathrm{mm})\end{array}$} & \multicolumn{6}{|c|}{$x=2 H$} & \multicolumn{6}{|c|}{$x=4 H$} \\
\hline & $0 \%$ & $64 \%$ & $69 \%$ & $78 \%$ & $72 \%$ & $58 \%$ & $0 \%$ & $64 \%$ & $69 \%$ & $78 \%$ & $72 \%$ & $58 \%$ \\
\hline 0 & 15.70 & 0.90 & 0.90 & 0.90 & 0.90 & 0.90 & 17.02 & 0.89 & 0.89 & 0.89 & 0.89 & 0.89 \\
\hline 25 & 15.46 & 15.52 & 15.65 & 15.94 & 15.75 & 15.32 & 20.28 & 20.64 & 20.65 & 20.67 & 20.66 & 20.63 \\
\hline 50 & 18.98 & 18.25 & 18.29 & 18.36 & 18.31 & 18.21 & 20.31 & 20.44 & 20.45 & 20.48 & 20.46 & 20.41 \\
\hline 75 & 21.41 & 20.95 & 20.94 & 20.92 & 20.93 & 20.96 & 20.64 & 20.59 & 20.60 & 20.62 & 20.60 & 20.58 \\
\hline 100 & 22.57 & 22.19 & 22.17 & 22.12 & 22.15 & 22.23 & 21.05 & 20.95 & 20.95 & 20.95 & 20.95 & 20.95 \\
\hline 150 & 22.77 & 22.61 & 22.58 & 22.51 & 22.56 & 22.66 & 21.54 & 21.43 & 21.42 & 21.41 & 21.42 & 21.45 \\
\hline 200 & 22.61 & 22.45 & 22.42 & 22.36 & 22.40 & 22.49 & 21.63 & 21.52 & 21.51 & 21.49 & 21.50 & 21.53 \\
\hline
\end{tabular}




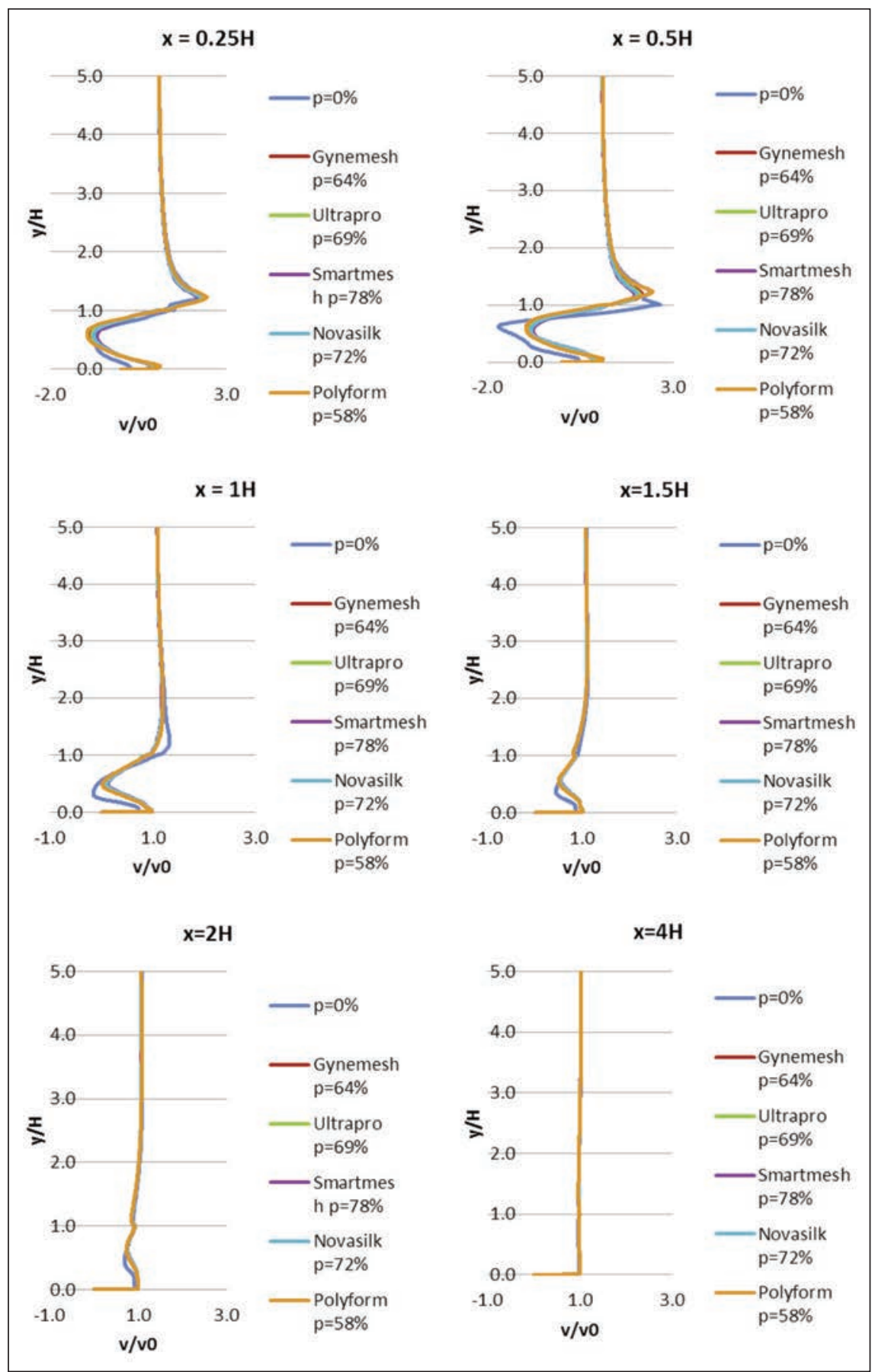

Fig. 5. Unadjusted speed for different porosity and distance from barrier (table 2) from which the values for drawing the graphs were taken in order to better visualize the obtained results. The graphs in figure 5 were made using unadjusted coordinates $v / v_{0}$ in the abscissa and $y / H$ in the ordered.

\section{CONCLUSIONS}

From the analysis of the results of the performed numerical tests, we can see that the $78 \%$ porosity is the most efficient in reducing the air velocity at the distance $x=0.25 \mathrm{H}$ and $x=0.5 \mathrm{H}$. For the $x=1 \mathrm{H}$ and $x=1.5 \mathrm{H}$ the porosity $58 \%$ is more efficient at the $25 \mathrm{~mm}$ height, but on average the $78 \%$ porosity is the best porosity to use, for all cases, including the $x=2 \mathrm{H}$ and $x=4 \mathrm{H}$, the later in which the flow velocity field resumes its normal course, the barrier no longer acting as an inertial loss for it. In order to validate the results obtained through the numerical tests and to capitalize on them, it will be possible to go further with the study of these simulations in the field of physical modeling, by carrying out experimental tests in the aerodynamic tunnel using these materials. Once these tests are carried out, the experimental results will be compared with the numerical ones, and the calculation model proposed in this paper will be updated and improved to simulate the phenomenon in nature. This will enable measures to be

After all the numerical simulations for the five types of textile materials used, a centralized table was created to highlight the results of the mathematical tests taken to reduce the effects of wind erosion in the areas affected by them using permeable protective barriers of textile material.

\section{REFERENCES}

[1] Lupe, I., Influenţa perdelelor forestiere asupra umezelii solului, In: Analele ICAS, 1951, 12, 1, 217-234

[2] Traci, C., Împadurirea terenurilor degradate, Ed. Ceres, Bucharest, 1985

[3] Neşu, I., Perdele forestiere de protecţie a câmpului, Ed. Star Tipp, Slobozia, 1999

[4] Nuță, S., Caracteristici structurale și funcționale ale perdelelor forestiere de protecție a câmpului agricol din sudul Olteniei, In: Analele ICAS, 2005, 48, 161-169

[5] Costăchescu, C., Dănescu, F., Mihăila, E., Perdele forestiere de protecţie, Ed. Silvică, Bucharest, 2010

[6] Feola, A., Barone, W., Moalli, P., Characterizing the ex vivo textile and structural properties of synthetic prolapse mesh products, In: International Urogynecology Journal, 2013, 24, 559-564 
[7] Yan, J., Quu, H., Numerical simulation of the effect of flow field in swirl nozzle spinning on yarn performance, In: Industria Textila, 2019, 70, 6, 564-571, http://doi.org/10.35530/IT.070.06.1422

[8] Degeratu, M., Hasegan, L., Alboiu, N., Bandoc, G., Modeling of the Atmospheric Boundary Layer using a Wind Tunnel with Discontinuity, In: Annals of DAAAM, 2010

[9] Degeratu, M., Georgescu, A.M., Bandoc, G., Alboiu, N.I., Cosoiu, C.I., Golumbeanu, M., Atmospheric boundary layer modeling as mean velocity profile used for wind tunnel tests on contaminant dispersion in the atmosphere, In: Journal of Environmental Protection and Ecology, 2013, 14, 1, 22-28

[10] Degeratu, M., Georgescu, A.M., Alboiu, N.I., Bandoc, G., Cosoiu, C.I., Golumbeanu, M., Turbulent structure of the wind flow and wind tunnel tests achieved for atmospheric contamination modelling, In: Journal of Environmental Protection and Ecology, 2013, 14, 2, 405-413

[11] Bandoc, G., Degeratu, M., Dragomir, E., Effect of wind turbulence on aeolian energy potential, In: Journal of Environmental Protection and Ecology, 2016, 17, 2, 541-548

Authors:

\section{BOGDAN-IULIAN DOROFTEI ${ }^{1}$, MIRCEA DEGERATU1 ${ }^{1}$, GEORGETA BANDOC², OVIDIU GEORGE IORDACHE ${ }^{3}$, IOANA CORINA MOGA 4}

${ }^{1}$ Department of Hydraulics and Environmental Protection, Technical University of Civil Engineering, Bucharest, Romania

${ }^{2}$ Department of Meteorology and Hydrology, University of Bucharest, Romania

${ }^{3}$ The National Research and Development Institute for Textiles and Leather, Bucharest, Romania

${ }^{4}$ Department of Research and Development, SC DFR Systems SRL, Bucharest, Romania

$$
\text { Corresponding author: }
$$

BOGDAN-IULIAN DOROFTEI

email: bogdan.doroftei@hotmail.com 